\title{
SPECIES DISTRIBUTION AND ANTIMICROBIAL SUSCEPTIBILITY OF ENTEROCOCCI ISOLATED FROM BROILERS INFECTED EXPERIMENTALLY WITH EIMERIA SPP AND FED WITH DIETS CONTAINING DIFFERENT SUPPLEMENTS
}

\author{
A.P.V. Cassenego ${ }^{1}$, P.A. d'Azevedo ${ }^{2}$, A.M.L. Ribeiro ${ }^{3}$, J. Frazzon ${ }^{4}$, S.T.Van Der Sand ${ }^{5}$, A. P. G. Frazzon ${ }^{5 *}$ \\ ${ }^{1}$ Programa de Pós-Graduação em Microbiologia Agrícola e do Ambiente, Universidade Federal do Rio Grande do Sul, Porto \\ Alegre, RS, Brasil; ${ }^{2}$ Departamento de Ciências Básicas da Saúde, Microbiologia, Universidade Federal de Ciências da Saúde de \\ Porto Alegre, Porto Alegre, RS, Brasil; ${ }^{3}$ Faculdade de Veterinária, Departamento de Zootecnia, Universidade Federal do Rio \\ Grande do Sul, Porto Alegre, RS, Brasil; ${ }^{4}$ Instituto de Ciência e Tecnologia de Alimentos, Universidade Federal do Rio Grande do \\ Sul, Porto Alegre, RS, Brasil; ${ }^{5}$ Instituto de Ciências Básicas da Saúde, Departamento de Microbiologia, Universidade Federal do \\ Rio Grande do Sul, Porto Alegre, RS, Brasil.
}

Submitted: May 24, 2010; Returned to authors for corrections: August 30, 2010; Approved: January 13, 2011.

\begin{abstract}
Resistant bacteria in animal can be spread to environment and to humans. Poultry feed and infections caused by Eimeria spp. are important factors in determining the intestinal microbial communities. The aim of this study was to verify the prevalence of species and antimicrobial susceptibility of Enterococcus isolated from broilers fed with different supplements and infected experimentally with Eimeria spp. Broilers were divided in eight groups, fed with diets supplemented with a combination of antimicrobial, ionophore-coccidiostatics, probiotic, essential oil. At 14 days old all birds, except the control, received a solution containing oocysts of Eimeria spp. Samples of cloacal swabs from broilers were collected. A total of 240 Enterococcus sp. strains were isolated, confirmed genus by PCR, classified as species, tested for antimicrobial susceptibility and screened by PCR for the presence of $\operatorname{tet}(\mathrm{L}), \operatorname{tet}(\mathrm{M})$ and $\operatorname{erm}(\mathrm{B})$ genes. The overall distribution of species isolated from fecal samples was E. faecalis (40\%), followed by E. casseliflavus/E. gallinarum (10.8\%), E. mundtii (10.8\%), E. faecium (10.8\%), E. columbae (5.8\%) and E. gallinarum (4.2\%). Changes in the composition or frequency of Enterococcus species were observed in all dietary supplementation. Antimicrobial susceptibility tests showed resistance phenotypes a range of antibiotics, especially used in humans such as, streptomycin, penicillin, rifampicin and vancomycin. There was no correlation between different supplementation for broilers and antimicrobial resistance and the presence of $\operatorname{tet}(\mathrm{M}), \operatorname{tet}(\mathrm{L})$ and $\operatorname{erm}(\mathrm{B})$ genes. Dietary supplementation had effect on the Enterococcus sp. colonization, but did not have significant effect on the phenotype and genotype of antimicrobial resistance in enterococci.
\end{abstract}

Key words: Enterococcus sp.; broilers feed; antimicrobial resistance; resistance genes.

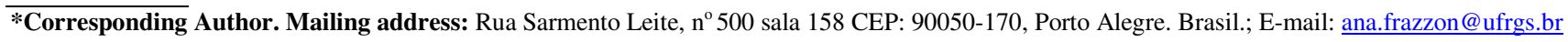




\section{INTRODUCTION}

The poultry industry worldwide has increased over the last 40 years. In 2009, world chicken meat production was 91.9 million tonnes (ton), and Brazil, United States and Europe are the world's largest exporters (12). Modern technologies of poultry production use massive doses of antimicrobial as therapeutics and for growth promotion, during all stages of production (23). The use of antimicrobial as growth promoter in animal feed has caused an increase in resistant bacteria isolated from animal (36). Almost all poultry dietary contain of 2 to $40 \mathrm{~g} /$ ton of any type of antimicrobial agent. In 2006, the European Union banned several antimicrobial growth promoters, however in Brazil, some growth promoters are used to feed commercial poultry and broilers chickens (43). The demand of products free of antibiotics and chemotherapy has led to the exploration of news to growth promoters, such as probiotics, prebiotics, and essential oils. In broiler nutrition, probiotic species belonging to genera Lactobacillus and Enterococcus are utilized to modulate intestinal microbial communities and pathogen inhibition (34). On the other hand, studies testing the addition of essential oils in the diet of broiler chickens have demonstrated in vitro antimicrobial, antiinflammatory, antioxidant and anticoccidiostatic activity of many plants $(29,43)$. Hume et al. (21) observed that essential oil supplemented in the diets avoided the drastic shifts after a mixed challenge of Eimeria spp. and the microbial communities were better modulated than monensin.

The feeding is an important factor in determining the intestinal microbial communities. Commensal enteric bacteria from chickens are frequently objects of researches, for supervision of animal products for human consumption and marketing. Enterococci are gram-positive bacteria widely distributed in the environment, inhabiting mainly the gastrointestinal tract of humans and animals (33). Furthermore, enterococci are opportunistic pathogens commonly associated with in immunocompromised patients and nosocomial infection (15). Enterococcus sp. resistant to several antimicrobials were isolated from clinical specimens and environment $(5,8,15,18,37)$. These microorganisms are intrinsically resistant against many antimicrobial agents commonly prescribed for Gram-positive cocci and exhibit resistance to a wide variety of other antimicrobials, by acquisition of resistance genes via transposons or plasmids, such as, tetracycline and macrolides (25). Resistance to tetracycline are mediated by two majors groups, the first includes the tet $(\mathrm{M}), \operatorname{tet}(\mathrm{O})$ and $\operatorname{tet}(\mathrm{S})$ genes that encoding ribosomal protection proteins, and the second is represented by tet $(\mathrm{L})$ and tet $(\mathrm{K})$ genes encodes tetracycline efflux pumps proteins (3). One of the most widespread mechanism of resistance to macrolides is mediated by methylation of a specific adenine residue in $23 \mathrm{~S}$ rRNA and is associated with the erm (B) gene (29).

In Brazil, few studies have investigated the presence of enterococci resistant in poultry $(28,43,44,47)$. The aim of this study was to verify the effect of diets containing different supplements and the presence or not of Eimeria spp. on the specific colonization and antimicrobial susceptibility of Enterococcus $\mathrm{sp}$. in the gastrointestinal tract of broilers.

\section{MATERIAL AND METHODS}

\section{Animals}

The study was conducted using a total of 250 day-old male Cobb 500. The broilers were housed indoors and distributed in a completely randomized design divided into eight treatment groups with five replicates each (12 birds/box). Broilers were fed with a diet based on corn-soybean meal, vegetable oil, minerals and vitamins and supplemented with a combination of ionophore-coccidiostatics (monensin) at $90 \mathrm{~g} / \mathrm{ton}$, probiotic (Enterococus faecium 3,5 x $10^{10} \mathrm{UFC} / \mathrm{g}$ ) at $35 \mathrm{~g} / \mathrm{ton}$, essential oil (extracted of thyme and clove) at $100 \mathrm{~g} /$ ton and/or antimicrobial (bacitracin methylene disalicylate $11 \%$ ) at 200g/ton. At 14 days old, all birds, expect 
the control, received a solution containing $5 \times 10^{4}$ and $1 \times 10^{4}$ oocysts/chicken of Eimeria maxima and Eimeria acervulina, respectively. The broilers were maintained until 28 days old at the Departamento de Zootecnia, Universidade Federal do Rio Grande do Sul. The nutritional requirements used are as indicated in Rostagno et al. (40).

\section{Isolation and confirmation of enterococci genus}

Five cloacal swabs samples from each group were collected and it was avoided environmental contamination (Table 1). Each swab was inserted into Cary-Blair medium and sent to the laboratory. The samples were inoculated in Broth Azide (Himedia, Mumbai, India) media for 24 hours at $35^{\circ} \mathrm{C}$. One hundred microliters of broth were inoculated on agar plates with Brain Heart Infusion agar (BHI) (Himedia, Mumbai, India) supplemented with $6.5 \% \mathrm{NaCl}$ and incubated as described above. Phenotypic criteria such as size/volume, shape, color, hemolytic profile, Gram staining, catalase production, and esculin hydrolysis tests were used to separate the enterococci and the non-enterococcal strains. Enterococci genus was confirmed by polymerase chain reaction (PCR) technique. DNA extraction and amplification using tuf gene followed the protocols described by Ke et al. (27) and Riboldi et al. (37). Thirty enterococci were randomly select from each group.

\section{Phenotype characterization of enterococci resistant}

The phenotype characterization was determined according to the protocol determined by Facklam et al. (12). Enterococcus faecalis ATCC 51299 and Staphylococcus aureus (ATCC 25923) were used as control strains.

PCR-RFLP of 16S ribosomal DNA to confirm the Enterococcus gallinarum and Enterococcus casseliflavus

Isolates biochemically classified as E. gallinarum or E. casseliflavus were confirmed by PCR-RFLP using primers specific region of $16 \mathrm{~S}$ ribosomal DNA, as described by
Medeiros et al. (32). Extraction of genomic DNA followed the method of Riboldi et al. (37). The PCR product of $661 \mathrm{bp}$ amplified was submitted to digestion with the restriction enzyme HinfI (Jena Bioscience GmbH, Germany) following the manufacturer instructions.

\section{Antimicrobial susceptible testing}

All isolates were subjected to antimicrobial susceptibility assay by disk diffusion method, as recommended by the Clinical and Laboratory Standards Institute (6). The following antimicrobials were tested: ampicillin (AMP $10 \mu \mathrm{g}$ ), penicillin (PEN $10 \mathrm{U}$ ), erythromycin (ERI $15 \mu \mathrm{g}$ ), streptomycin (STR 10 $\mathrm{mg}$ ), chloramphenicol (CLO $30 \mu \mathrm{g}$ ), ciprofloxacin (CIP $5 \mu \mathrm{g}$ ), nitrofurantoin (NIT $300 \mu \mathrm{g}$ ), vancomycin (VAN $30 \mu \mathrm{g}$ ), rifampicin (RIF $5 \mu \mathrm{g}$ ) and tetracycline (TET $30 \mu \mathrm{g}$ ). As positive and negative controls strains E. faecalis ATCC 51299 and E. faecium ATCC 53519 were used, respectively.

\section{Detection of $\operatorname{tet}(\mathrm{M}), \operatorname{tet}(\mathrm{L})$ and $\operatorname{erm}(\mathrm{B})$ genes:}

All strains were tested for the presence of $\operatorname{tet}(\mathrm{M}), \operatorname{tet}(\mathrm{L})$ and erm(B) genes by PCR. Enterococcus sp. genomic DNA was extracted by the boiling method as described by Riboldi et al. (37). The primer of $\operatorname{tet}(\mathrm{M}), \operatorname{tet}(\mathrm{L})$ and $\operatorname{erm}(\mathrm{B})$ genes and PCR amplifications were performed as described by Frazzon et al. (15).

\section{Statistical analysis}

The experimental data was submitted to analysis of variance using the Program SASM-AGRI for Statistical Significant Differences at $\mathrm{P}<0.05$ and $\mathrm{P}<0.01$ (2).

\section{RESULTS AND DISCUSSION}

\section{Identification of enterococci isolates}

A total of 240 Enterococcus were isolated and confirmed the genus through PCR. Table 1 shows the overall distribution of species identified in fecal samples from broilers. Sixteen 
different species were identified and E. faecalis was the most prevalent specie (40\%), followed by E. casseliflavus/E. gallinarum (10.8\%), E. mundtii (10.8\%), E. faecium (10.8\%), E. columbae $(5.8 \%)$ and E. gallinarum $(4.2 \%)$. Other species identified were E. pseudoavium, E. saccharolyticus, E. avium, E. hirae, E. durans, E. cecorum, E. sulfureus, E. asini, E. malodoratus and E. raffinosus characterizing $10 \%$ of the isolates. Sixteen isolates $(6.6 \%)$ could not be identified to the species level, and were classified as Enterococcus sp. The species identified in the current study were also reported by Hwang et al. (23), Fracalanzza et al. (14), Debnam et al. (9) for broilers and chicken meat. Enterococci are part of the gastrointestinal microbiota of chickens (17). In chickens, the presence of Enterococcus species varies with age of birds. In young birds the most prevalent species are E. faecalis and E. faecium, with the maturity of the birds there is a decline in $E$. faecium, followed by E. faecalis, allowing the growth of other species (10). The prevalence of E. casseliflavus/E. gallinarum was relatively higher in the present study compared to other countries $(9,23)$. Meanwhile, some studies conducted in Brazil have been observed high prevalence of these species from samples of chicken meat $(15,14)$.

Table 1. Groups, supplements and distribution of Enterococcus species from broilers feed with different dietary supplemented.

\begin{tabular}{|c|c|c|c|c|c|c|c|}
\hline \multirow[b]{2}{*}{ Group $^{\text {diets }}$} & \multicolumn{7}{|c|}{ Number of isolates $(\%)$} \\
\hline & E. faecalis & $\begin{array}{l}\text { E.casseliflavus/ } \\
\text { E.gallinarum }\end{array}$ & E. munditti & E. faecium & E. gallinarum & E. columbae & Other species $^{2}$ \\
\hline $1^{\mathrm{a}}$ & $15(50)$ & $4(13.3)$ & $1(3.3)$ & 0 & $3(10)$ & 0 & $7(23.3)$ \\
\hline $2^{b}$ & $18(60)$ & 0 & 0 & $2(7)$ & 0 & $5(16.6)$ & $5(16.6)$ \\
\hline $3^{c}$ & $17(56.6)$ & $3(10)$ & $5(16.6)$ & 0 & 0 & $1(3)$ & $4(13.3)$ \\
\hline $4^{\mathrm{d}}$ & $11(36.6)$ & $3(10)$ & $4(13.3)$ & $5(17)$ & $3(10)$ & 0 & $4(13.3)$ \\
\hline $5^{\mathrm{e}}$ & $5(16.6)$ & $7(23)$ & $4(13.3)$ & $5(17)$ & $1(3.3)$ & $3(10)$ & $5(16.6)$ \\
\hline $6^{\mathrm{f}}$ & $7(23)$ & $5(16.6)$ & $7(23)$ & $1(3.3)$ & $2(6.6)$ & $1(3.3)$ & $7(23.3)$ \\
\hline $7^{\mathrm{g}}$ & $13(43.3)$ & $3(10)$ & $1(3.3)$ & $5(17)$ & $1(3.3)$ & $3(10)$ & $4(13.3)$ \\
\hline $8^{\mathrm{h}}$ & $10(33.3)$ & $1(3.3)$ & $4(13.3)$ & $8(26.6)$ & $2(6.6)$ & $1(3.3)$ & $4(13.3)$ \\
\hline Total & $96(40)$ & $26(10.8)$ & $26(10.8)$ & $26(10.8)$ & $10(4.2)$ & $14(5.8)$ & $40(16.6)$ \\
\hline
\end{tabular}

Diets: a) unmedicated infected control; b) ionophore coccidiostatic infected group; c): probiotic infected group; d) ionophore coccidiostatic and probiotic infected group; e) essential oil infected group; f) ionophore coccidiostatic and essential oil infected group; g) growth promoter infected group; h) unmedicated uninfected control $^{2:}$ E. pseudoavium, E. saccharolyticus, E. avium, E. hirae, E. durans, E. cecorum, E. sulfureus, E. asini, E. malodoratus and E. raffinosus and Enterococcus spp.

Of the 39 isolates classified as E. casseliflavus and E. gallinarum and tested by PCR-RFLP, only two isolates did not showed DNA fragments pattern expected to E. gallinarum and E. casseliflavus, and were reclassified as Enterococcus sp. The correct identification of these species is very important to distinguish between intrinsic and acquired resistance to vancomycin.

\section{Species distribution according to dietary supplement employed}

Changes in the composition or frequency of Enterococcus species were noticed (Table 1). The species distribution between all groups was comparable with the control. The unmedicated, uninfected control (group 8) the most prevalent species were E. faecalis $(33.3 \%)$, E. faecium $(26.6 \%)$, E.mundtii (13.3\%), E. gallinarum (6.6\%), E. casseliflavus/E. gallinarum (3.3\%), E. columbae (3.3\%), and Enterococcus sp. $(13.6 \%)$. Changes in the composition of Enterococcus species were detected in groups 1, 2, 3 and 4. In group 1 (unmedicated, infected control) no E. faecium, E. columbae and E.mundtii were isolated. One reason for this change in the species frequency should be due the intestinal dysbacteriosis caused by Eimeria spp. Fukata et al. (16) reported that chickens infected with Eimeria tenella showed a change in the 
composition of the intestinal microbiota, compared to uninfected chickens. In group 2 (ionophore-coccidiostatic, infected) E. casseliflavus/E.gallinarum, E. gallinarum, and E. mundtii were isolated. Monensin is a polyether antibacterial of the ionophore group, and demonstrate an anticoccidial action against E. tenella, E. acervulina, E. mivati, E. brunetti, E. maxima, E. necatrix in chickens. Since monensin is antibacterial agent, it may have an effect against some enterococcus species (41). Debnam et al. (10) verified that antibiotic virginiamycin had a negative effect of some enterococcus species. In swabs from group 3 (probiotic, infected) no E. faecium and E. gallinarum were isolated and from group 4 (ionophore-coccidiostatic and probiotic, infected) E. columbae was detected, but E. faecium and E. gallinarum were observed. The diarrhea caused by Eimeria spp. in the broilers from group 3 may have been impaired the colonization of the gut by E. faecium (probiotic) and eliminated the probiotic and, may possibly be the reason why this species was not detected in group 3. The association ionophorecoccidiostatic and probiotic appeared to have a positive effect on this species. The reduction in the prevalence of some species detected in groups 3 and 4 should be caused by the presence of probiotics in the diet of broilers, since probiotic microorganisms has the ability to produce inhibitory substances (antagonize other microorganism) and also competitive capacity (hydrophobic cell wall, that facilitate adhesion to the epithelium intestinal) (44). Changes in the frequency of Enterococcus species were perceived in groups 5, 6 and 7. In groups 5 (essential oil, infected) and 6 (ionophorecoccidiostatic and essential oil, infected) an increase of $20 \%$ and $13 \%$ in the frequency of E. casseliflavus/E.gallinarum, respectively, was observed. In the group 6 , the highest prevalence of E. pseudoavium (20\%) was identified, showing that the association ionophore-coccidiostatic and essential oil have a positive effect on this specie. Alterations in the frequency of some enterococcus species observed in groups 5 and 6 should be caused by essential oil. Antibiotic and anticoccidial activity of plants oil against Eimeria spp. are well known $(29,43)$. In the broilers receiving antibiotic and were infected with Eimeria spp. (group 7), variations in the frequency of Enterococcus species were noted. The antibiotic in the supplement, should selected the most adapted organisms inside the gut of broilers. Leme et al. (28) have demonstrated that broilers fed with feed supplemented with avoparcin as growth promoter showed an increase of E. faecium when compared with control group.

\section{Antimicrobial susceptibility according to dietary supplement used}

Table 2 shows the antibiotic susceptibility of Enterococcus species isolated from cloacae of poultries. The prevalence of antimicrobial resistance between all groups was compared, and an increase or decreases in frequency of resistance as observed. Absence of susceptibility to at least one of the antimicrobials tested was detected, except to the antimicrobial ampicillin. Enterococcus sp. ampicillin-susceptible has been related in isolated from chickens and food $(38,44)$.

Resistance to tetracycline was verified in all groups (56.7\%-100\%). Although tetracycline is an antimicrobial not approved by the European Union as a food supplement for chickens, therapeutic and prophylactic use in veterinary is common, and Enterococcus resistant to tetracycline are frequently found in broilers, animal feed, poultry production environment and chicken carcasses $(7,15,20)$. The higher percentage of erythromycin resistant enterococcus was noticed in groups 1, 3, 4, 5 and 7 (53-70\%). Hwang et al. (23) observed same prevalence of erythromycin resistance in enterococcus isolated from fecal samples of chicken in Korea. The erythromycin resistant enterococcus is very interesting, since this drug is the choice for treatment of several infection and also enterococcal infection in penicillin-allergic patients.

An increase in the percentage of Enterococcus sp. resistant to penicillin was observed in groups 13,4 , and 7 . The prevalence of penicillin-resistant enterococcus are presented 
here was highest, contrasting to the results reported by Aarestrup et al. (1) and Hayes et al. (20), where low levels of penicillin-resistant enterococcus isolated from chickens were detected, in spite of the fact that San Martín et al. (42) have found a high percentage of enterococci resistant to penicillin in broilers samples. Penicillin-resistant enterococci isolate from poultries is important, for the reason that the animals can serve as an important reservoir of resistant bacteria that can be spread to humans through the food chain and also by the reason that penicillin is the basis of therapy of enterococcal infection (36). A lower prevalence of erythromycin-resistant enterococci (7\%) was perceived in group 2. However, Jacob et al. (24) had reported that ionophore-coccidiostatics (monensin) in pigs increased prevalence of erythromycin-resistant enterococci.
The difference observed between the previous study and results showed here, may be caused by the lower concentration of erythromycin $(8 \mathrm{mg})$ used by Jacob et al. The interactions ionophore-coccidiostatics and probiotic (group 4) and ionophore-coccidiostatics and essential oil (group 6) increased the prevalence of Enterococcus sp. resistant to chloramphenicol. The presence of enterococci resistant to chloramphenicol is undesirable, because the use of this drug is prohibited in Brazil (44). However, chloramphenicol-resistant enterococci have already been observed in isolates from broilers $(20,42)$. Among the 240 enterococcus isolated from broilers, $183(76.7 \%)$ were resistant to 2 or more antimicrobial tested. Multi drug resistant Enterococcus sp. has been isolated from broilers and chicken meat $(14,15,40)$.

Table 2. Frequency of antimicrobial resistance patterns in Enterococcus sp. isolated from cloacal swabs of broilers feed with different dietary supplemented

\begin{tabular}{|c|c|c|c|c|c|c|c|c|c|c|}
\hline \multirow[b]{2}{*}{ Group } & \multicolumn{10}{|c|}{ Resistance $\%$ to $^{\text {a }}$} \\
\hline & AMP & PEN & VAN & CIP & ST & RIF & CLO & NIT & TET & ERI \\
\hline $1^{*}$ & 0 & 67.7 & 0 & 0 & 3.3 & 23.3 & 0 & 0 & 56.7 & 50 \\
\hline $2^{*}$ & 0 & 40 & 10 & 6.6 & 3.3 & 33.3 & 0 & 0 & 100 & 6.6 \\
\hline $3^{*}$ & 0 & 56.7 & 3.3 & 16.6 & 16.6 & 60 & 0 & 0 & 100 & 53.3 \\
\hline $4^{*}$ & 0 & 60 & 6.6 & 3.3 & 46.7 & 26.7 & 13.3 & 0 & 90 & 70 \\
\hline $5^{*}$ & 0 & 33.3 & 3.3 & 0 & 43.3 & 20 & 0 & 6.6 & 100 & 53.3 \\
\hline $6^{*}$ & 0 & 33.3 & 0 & 6.6 & 13.3 & 20 & 6.6 & 3.3 & 87 & 26.7 \\
\hline $7^{*}$ & 0 & 50 & 6.6 & 0 & 23.3 & 63.3 & 3.3 & 0 & 93 & 53.3 \\
\hline 8 & 0 & 30 & 3.3 & 6.6 & 6.6 & 56.7 & 0 & 3.3 & 97 & 10 \\
\hline
\end{tabular}

antibiotics: ampicillin (AMP), penicillin (PEN),vancomycin (VAN), ciprofloxacin (CIP), streptomycin (ST), rifampicin (RIF), chloramphenicol (CLO), nitrofurantoium (NIT), tetracycline (TET), erythromycin (ERI). * Broilers inoculated with Eimeria spp.

An interesting observation of this study was vancomycinresistant enterococcus (VRE). In Brazil, few studies have been focused on VRE in broilers. Souza et al. (44) detected a high of the VRE isolated from commercial broilers, however Xavier et al. (46-47) have not detected VRE in cloacal swabs collected from poultry. The differences observed in these studies could be due to several factors, including stage of production, which samples were taken.
Dietary supplementations did not influence the resistance profile in enterococcus isolated from broilers. Some explanations to this should be: i) resistant bacteria may persist on production equipments or in other parts of the production environment that are difficult to decontaminates (7, 19); ii) there is the possibility the resident birds, small rodents or insects work as carries of resistant bacteria (35) and also iii) the poultry feed and feed ingredients could be the source of 
resistant enterococcus (7).

\section{Frequency of $\operatorname{tet}(\mathrm{M}), \operatorname{tet}(\mathrm{L})$ and $\operatorname{erm}(\mathrm{B})$ genes.}

All strains were tested for the presence of $\operatorname{tet}(\mathrm{M}), \operatorname{tet}(\mathrm{L})$ and $\operatorname{erm}(\mathrm{B})$ genes by PCR. The $\operatorname{tet}(\mathrm{M})$ was present in $62 \%$, $\operatorname{tet}(\mathrm{L})$ in $3.8 \%$ and $\operatorname{tet}(\mathrm{M})$ and $\operatorname{tet}(\mathrm{L})$ in $23.3 \%$ of isolates. The prevalence of these genes is consistent with other previous studies in poultry and chicken meat $(1,2,12)$. Five strains susceptible to tetracycline carried, at least one of the tet genes. This can be attributed to the lack of expression of the resistance gene, as described by Martineau et al. (31) and Martel et al. (30), and Frazzon et al. (15). In our study, $94 \%$ and $30 \%$ of tetracycline resistance strains showed the presence of tet $(\mathrm{M})$ and $\operatorname{tet}(\mathrm{L})$ genes, respectively. Huys et al. (22) observed in Enterococcus sp. tetracycline resistance strains isolated from food a prevalence of $95 \% \operatorname{tet}(\mathrm{M})$ and $35 \% \operatorname{tet}(\mathrm{L})$ genes.

The $\operatorname{erm}(\mathrm{B})$ gene was detected in $39.6 \%$ of all isolates and $97.9 \%$ of erythromycin resistant present the erm(B) gene. This gene is frequently observed in enterococci of animal origin and is reported to be the most common gene for resistance to macrolides $(1,24)$. Evidence of dissemination of erythromycin resistance has been shown in Enterococcus sp. isolated from pigs, chickens and humans (11). Furthermore, eighty four isolates positive for tet(M) also contained erm(B) gene. In most cases, $\operatorname{tet}(\mathrm{M})$ is carried by conjugative transposons such as $\operatorname{Tn} 916 / \operatorname{Tn} 1545$ and in this plasmids tet(M) is associated with $\operatorname{erm}(\mathrm{B})(5,39)$.

Dietary supplementation did not have significant effect on the presence of tet(M), tet $(\mathrm{L})$ and $\operatorname{erm}(\mathrm{B})$ genes. Jacob et al. (24), also were reported that steam-flaked corn diet with wet distillers grains for cattle, did not affect the presence of either $\operatorname{tet}(\mathrm{M})$ or $\operatorname{erm}(\mathrm{B})$ genes, in fecal samples.

To our knowledge, this is the first study to report the distribution and antimicrobial resistance in Enterococcus sp. in relation to dietary supplementation for broilers in Brazil. Dietary supplementation had effect on the Enterococcus sp. colonization, but did not have significant effect on the phenotype and genotype of antimicrobial resistance in enterococci. The presence of resistant enterococci in feces of broilers is very important, for the reason that these bacteria can spread to environment and to humans, through the food chain or dropping or aerosol particles, which can be inhaled by healthy individuals.

\section{ACKOWLEDGEMENTS}

Conselho Nacional de Desenvolvimento Científico e Tecnológico (CNPq), Coordenação de Aperfeiçoamento de Pessoal de Nivel Superior (CAPES) and Fundação de Amparo a Pesquisa do Rio Grande do Sul (FAPERGS).

\section{REFERENCES}

1. Aarestrup, F.M.; Agerso, Y.; Gerner-Smidt, P.; Madsen, M.; Jensen, L.B. (2000). Comparison of antimicrobial resistance phenotypes and resistance genes in Enterococcus faecalis and Enterococcus faecium from humans in the community, broilers, and pigs in Denmark. Diagn. Microbiol. Infect. Dis. 37, 127-137.

2. Canteri, M.G.; Althaus, R.A.; Virgens Filho, J.S.; Giglioti, E.A.; Godoy, C.V. (2001). SASM-Agri: Sistema para análise e separação de médias em experimentos agrícolas pelos Métodos Skoft-Knot, Tukey e Duncan. Revista Brasileira de Agrocomputação. 1(2), 18-24.

3. Cauwerts, K.; Decostere, A.; De Graef, E.M.; Haesebrouck, F.; Pasmans, F. (2007). High prevalence of tetracycline resistance in Enterococcus isolates from broilers carrying the erm (B) gene. Avian. Pathol. 36, 1-2.

4. Chopra, I., M. Roberts. (2001). Tetracycline antibiotics: mode of action, applications, molecular biology, and epidemiology of bacterial resistance. Microbiol. Mol. Biol. Rev. 65, 232-260.

5. Clewell, D.B.; Jaworski, D.D.; Flannagan, S.E.; Zitzow, L.A.; Su, Y.A. (1995). The conjugative transposon Tn916 of Enterococcus faecalis: structural analysis and some key factors involved in movement. In J. J. Ferretti, M. S. Gilmore, T. R.Klaenhammer, and F. Brown (Eds.), Genetics of Streptococci, Enterococci, and Lactococci. Developments in Biological Standardization. 85, p.11-15.

6. Clinical and Laboratory Standards Institute (CLSI) (2008). Performance standard for antimicrobial susceptibility testing. Tables M100- S18 2008 and MS 100-15. 25, 1. 
7. Costa, P.M.; Oliveira, M.; Bica, A.; Vaz-Pires, P.; Bernardo, F. (2007). Antimicrobial resistance in Enterococcus spp. and Escherichia coli isolated from poultry feed and feed ingredients. Vet. Microbiol. 120, 122131.

8. d'Azevedo, P.A.; Dias, C.A.G.; Teixeira, L. M. (2006). Genetic diversity and antimicrobial resistance of enterococcal isolates from southern region of Brazil. Rev. Inst. Med. Trop. S. Paulo. 48, 11-16.

9. Debnam, A.L.; Jackson, C.R.; Avellaneda, G.E.; Barrett, J.B.; Hofacre, C.L. (2005). Effect of growth promotant usage on enterococci species on a poultry farm. Avian Dis. 49(3), 361-5.

10. Devriese, L.A.; Baele, M.; Butaye, P. (2006). The Genus Enterococcus: Taxonomy. Prokaryotes. 4, 163-174.

11. De Leener, E.; Martel, A.; Decostere, A.; Haesebrouck, F.(2004) Distribution of the erm (B) gene, tetracycline resistance genes, and Tn1545-like transposons in macrolide- and lincosamide-resistant enterococci from pigs and humans.(2004) Microb. Drug. Resist. 4, 341345.

12. Food and Agriculture Organization of the United Nations. 2009. Available at: www.fao.org/docrep/012/ak341e/ak341e09.htm. Accessed 05.02 .2010

13. Facklam, R.R.; Carvalho, M.R.S.; Teixeira. L.M. (2002). History, taxonomy, biochemical characteristics, and antibiotic susceptibility testing of enterococcis. In: Gilmore, M.S. (ed.). The Enterococci:Pathogenesis, Molecular Biology, and Antibiotic Resistance. ASM Press, Washington, D.C.

14. Fracalanzza, S.A.P.; Scheidegger, E.M.D.; Santos, P.F.; Leite, P.C.; Teixeira, L.M. (2007). Antimicrobial resistance profiles of enterococci isolated from poultry meat and pasteurized milk in Rio de Janeiro, Brazil. Mem. Inst. Oswaldo Cruz. 102 (7), 853-859.

15. Frazzon, A.P.G.; Gama, B.A.; Hermes, V.; Bierhals, C.G.; Pereira, R.I.; Guedes, A.C.; d'Azevedo, P.A.; Frazzon, J. (2009). Prevalence of antimicrobial resistance and molecular characterization of tetracycline resistance mediated by tet $(\mathrm{M})$ and tet $(\mathrm{L})$ genes in Enterococcus spp. isolated from food in Southern Brazil. World J. Microbiol. Biotechnol. 26, 365-370.

16. Fukata, T.; Kageyama, A.; Baba, E.; Arakawa, A. (1987). Effect of infection with Eimeria tenella upon the cecal bacterial population in monoflora chickens. Poult. Sci. 66, 841-844.

17. Giraffa, G. (2002). Enterococci from foods. FEMS Microbiol. Rev. 26, 163-171.

18. Gomes, B.C.; Esteves, C.T.; Palazzo, I.C.V.; Darini, A.L.C.; Felis, G.E.; Sechi, L.A.; Franco, B.D.G.M.; Demartinis, E.C.P. (2008). Prevalence and characterization of Enterococcus spp. isolated from Brazilian foods. Food Microbiol. 25, 668-675.

19. Graham, J.P.; Price, L.B.; Evans, S.L.; Graczyk, T.K.; Silbergeld, E.K. (2009). Antibiotic resistant enterococci and staphylococci isolated from flies collected near confined poultry feeding operations. Sci. Total
Environ. 407 (8), 2701-2710.

20. Hayes, J.R.; English, L.L.; Carter, P.J.; Proescholdt, T.; Lee, K.Y.; Wagner, D.D.; White, D.G. (2003). Prevalence and antimicrobial resistance of Enterococcus species isolated from retail meats. Appl. Environ. Microbiol. 69, 7153-7160.

21. Hume, M.E.; Clemente-Hernández, S.; Oviedo-Rondón, E.O. (2006). Effects of feed additives and mixed Eimeria species infection on intestinal microbial ecology of broilers. Poult. Sci. 85, 2106-2111.

22. Huys, G.; D'haene, K.; Collard, J. M.; Swings, J. (2004). Prevalence and molecular characterization of tetracycline resistance in Enterococcus isolates from food. Appl. Environ. Microbiol. 70 (3), 1555-1562.

23. Hwang, I.Y.; Ku, H.O.; Lim, S.K.; Park, C.K.; Jung, G.; Jung, S.C.; Nam H.M. (2009). Species distribution and resistance patterns to growthpromoting antimicrobials of enterococci isolated from pigs and chickens in Korea. J. Vet. Diagn. Invest. 21(6):858-62.

24. Jacob, M.E.; Fox, J.T.; Narayanan, S.K.; Drouillard, J.S.; Renter, D.G.; Nagaraja, T.G. (2008). Effects of feeding wet corn distillers grains with solubles with or without monensin and tylosin on the prevalence and antimicrobial susceptibilities of fecal foodborne pathogenic and commensal bacteria in feedlot cattle. J. Anim. Sci. 86, 1182-1190.

25. Jackson, C.R.; Fedorka-Cray, P.J.; Barrett, J.B.; Ladely, S.R. (2004). Effects of Tylosin use on Erythromycin resistance in enterococci isolated from swine. Appl. Environ. Microbiol. 70(7), 4205-4210.

26. Kak, V.; Chow, J.W. (2002). Acquired antibiotic resistances in enterococci. In: Gilmore, M.S. The enterococci: pathogenesis, molecular biology, and antibiotic resistance. 355-376.

27. Ke, D.; Picard, F.J.; Martineau, F.; Menard, C.; Roy, P.H.; Ouellette, M.; Bergeron, M.G. (1999). Development of a PCR assay for rapid detection of Enterococci. J. Clin. Microbiol. 37, 3497-3503.

28. Leme, I.L.; Ferreira, A.J.P.; Bottino, J.A.; Pignatari, A.C.C. (2000). Glycopeptides susceptibility among enterococci isolated from a poultry farm in São Paulo, Brazil (1996/1997). Braz. J. Microbiol. 31, 53-57.

29. Manzanilla, E.G.; Perez, J.F.; Martin, M.; Kamel, C.; Baucells, F.; Gasa, J. (2004). Effect of plant extracts and formic acid on the intestinal equilibrium of early-weaned pigs. J. Anim. Sci. 82, 3210-3218.

30. Martel, A.; Meulenaere, V.; Devriese, L.A.; Decostere, A.; Haesebrouck, F. (2003). Macrolide and lincosamide resistance in the gram-positive nasal and tonsilar flora of pigs. Microb. Drug Resist. 9, 293-297.

31. Martineau, F.; Picard, F.J.; Lansac, N.; Menard, C.; Roy, P.H.; Ouellette, M.; Bergeron, M.G. (2000). Correlation between the resistance genotype determined by multiplex PCR assays and the antibiotic susceptibility patterns of Staphylococcus epidermidis. Antimicrob. Agents Chemother. 44, 231-238.

32. Medeiros, A.W.; d'Azevedo, P.A.; Pereira, R.I.; Cassenego, A.P.V.; Van Der Sand, S.; Frazzon, J.; Frazzon, A.P.G. (2010). PCR-RFLP of $16 \mathrm{~S}$ ribosomal DNA to confirm the Enterococcus gallinarum and Enterococcus casseliflavus identification isolated from clinical and food 
samples. Rev. Soc. Bras. Med. Trop. 43, 1-2.

33. Moreno, M.R.; Sarantinopoulos, P.; Tsakalidou, E.; Devuyst, L. (2006). The role and application of enterococci in food and health. Int. J. Food Microbiol. 106, 1-24.

34. Mountzouris, K.C.; Tsirtsikos, P.; Kalamara, E.; Nitsch, S.; Schatzmayr, G.; Fegeros, K. (2007). Evaluation of the efficacy of a probiotic containing Lactobacillus, Bifidobacterium, Enterococcus, and Pediococcus strains in promoting broiler performance and modulating cecal microflora composition and metabolic activities. Poult. Sci. 86 , 309-317.

35. Nesse, L.L.; Nordby, K.; Heir, E.; Bergsjoe, B. Vardund, T.; Nygaard, H.; Holstad, G. (2003). Molecular analyses of Salmonella enterica isolates from fish feed factories and fish feed ingredients. Appl. Environ. Microbiol. 2, 1075-1081.

36. Poeta, P.; Antunes, T.; Rodrigues, J. (2005). Enterococcus spp. resistentes à vancomicina isolados de fezes de frangos, pombos, gamos e ratos. Arq. Bras. Med. Vet. Zootec. 58, 412-414.

37. Riboldi, G.P.; Mattos, E.P.; Frazzon, A.P.G.; d'Azevedo, P.A.; Frazzon, J. (2008). Phenotypic and genotypic heterogeneity of Enterococcus species isolated from food in Southern. Brazil. J. Basic Microbiol. 48, 31-37.

38. Riboldi, G.P.; Frazzon, J.; d'Azevedo, P.A.; Frazzon, A.P.G. (2009). Antimicrobial resistance profile of Enterococcus spp. isolated from food in Southern Brazil. Braz. J. Microbiol. 40, 125-128.

39. Rice, L.B.; Carias, L.L. (1998). Transfer of Tn5385, a composite, multiresistance chromosomal element from Enterococcus faecalis. $J$. Bacteriol. 180 (3), 714-721.

40. Rostagno, H.S.; Albino, L.F.T.; Donzele, J.L.; Gomes, P.C.; Oliveira, R.F.; Lopes, D.C.; Ferreira, A.F.; Barreto, S.L.T. (2005). Tabelas brasileiras para aves e suínos: Composição de Alimentos e Exigências Nutricionais. $2^{\mathrm{a}}$ ed. UFV-Departamento de Zootecnia, Viçosa.

41. Russell, J.B. (1987). A proposed mechanism of monensin action in inhibiting ruminal bacterial growth: effects on ion flux and proton motive force. Anim. Sci. J. 64, 1519-1525.

42. San Martín, B.; Campos, L.; Bravo, V.; Adasne, M.; Borie, C. (2005). Evaluation of antimicrobial resistance using indicator bacteria isolated from pigs and poultry in Chile. Intern. J. Appl. Res. Vet. Méd. 2, 171178 .

43. Silva, M.A.; Pessotti, B.M.S.; Zanini, S.F.; Colnago, G.L.; Rodrigues, M. R.A.; Nunes, L.C.; Zanini, M.S.; Martins, I.V.F. (2009). Intestinal mucosa structure of broiler chickens infected experimentally with Eimeria tenella and treated with essential oil of oregano Cienc. Rural .5, 1471-1477.

44. Souza, M.R.; Moreira, J.L.; Barbosa, F.H.F.; Cerqueira, M.M.O.P.; Nunes, A.C.; Nicoli, J.R. (2007). Influence of intensive and extensive breeding on lactic acid bacteria isolated from Gallus gallus domesticus ceca. Vet. Microbiol. 120, 142-150.

45. Sutcliffe, J.; Grebe, T.; Tait-Kamradt, A.; Wondrack, L. (1996). Detection of erythromycin-resistant determinants by PCR. Antimicrob. Agents Chemother. 40, 2562-2566.

46. Xavier, D.B.; Bernal, F.E.M.; Almeida, R.T. (2006). Absence of vanAand vanB-containing enterococci in poultry raised on non-intensive production farms from Brazil. Appl. Environ. Microbiol. 72 (4), 30723073.

47. Xavier, D.B.; Bernal, F.E.M.; Almeida, R.T. (2008). Prevalence of Enterococcus spp. isolated from free-range chickens in different regions of Distrito Federal, Brazil. Arq. Bras. Med. Vet. Zootec. 6, 1550-1553. 